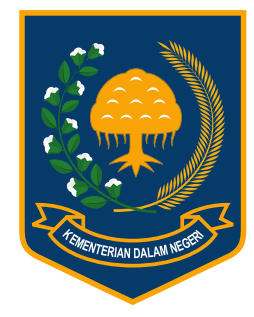

Jurnal Bina Praja 8 (1) (2016): 13-26

Jurnal Bina Praja

e-ISSN: 2503-3360 | p-ISSN: 2085-4323

Accreditation Number

735/AU2/P2MI-LIPI/04/2016

http://jurnal.kemendagri.go.id/index.php/jbp/index

\title{
INCREASING THE SCOPE OF BIRTH AND DEATH REGISTRATION: ISSUES AND CHALLENGES
}

\author{
Hari Prasetyo ${ }^{1,}{ }^{*}$, Moh. Ilham A. Hamudy ${ }^{2}$ \\ ${ }^{1,2}$ Research and Development Agency, Ministry of Home Affairs (BPP Kemendagri) \\ Jl. Kramat Raya No. 132, Senen, Jakarta Pusat
}

Received: 4 March 2016; Accepted: 2 May 2016; Published online: 31 May 2016

\begin{abstract}
Despite being regulated by the Presidential Decree No 25 of 2008, which then was simplified by the Law No 24 of 2013, the registration of birth and death in Indonesia does not automatically promote the scope of birth and death certificate in Indonesia. Local governments are with their respective innovations on these issue, yet these inovations tend to add more bureaucracy and create new problems. The purpose of this study is to examine how the real practice of birth and death registration, as well as to identify the problems, implications, and the causes of the registration implementation. This study was conducted in 2015 in two districts and two municipalities in Banten and West Java Provinces using descriptive research method and descriptive-qualitative analysis. This study found that birth and death registration are still referring to the Presidential Decree No 25 of 2008 which implementation is still adapting the "convenience" of the Law No 24 of 2013. The implementation of birth and death registration still experiences many obstacles, such as: the lack of death reporting by the head of neighborhood (RT); applicants still experience tiered bureaucracy that leads to a lengthy process of completing the document, limited access in the district area, and time service mismatch; human resources in the sub-district/village that are not adequately supportive to the civil registration services; and documentation process in the implementing agencies still relies on manual systems.
\end{abstract}

Keywords: civil registration, birth certificate, death certificate

\section{INTRODUCTION}

This study is about the implementation of birth and death registration. The term of birth and death registration in this study is actually referring to the term of civil registration as set forth on Law No 24 of 2013 about Population Administration and Presidential Decree No 25 of 2008 about the Terms and Procedures for Population Registration and Civil Registration.

In the regulation, civil registration is interpreted as recording important events experienced by a person in the register of civil registration of the implementing agency. The important events mentioned are the events experienced by a person which includes birth, death, stillbirth, marriage, divorce, child recognition, child validation, adoption, change of name, and change of citizenship status. Nonetheless, this study focuses only on registration of birth and death.

The study on birth registration is in fact already quite a lot. However, the study on the implementation of birth and death registration based particularly on Law No 24 of 2013 and the Presidential Decree No 25 of 2008 is very minimal if not to say does not exist. Most of the existing studies only discuss about the birth certificate provision service conducted by the Population and Civil Registration Agency. It can be seen on studies conducted by Suffiani (2012), Prasetya (2012), Syaibani (2010), and Jackson et.al (2014). Others studies also worth mentioning are written by Ambiyah (2011) and Udia (2012).

Ambiyah (2011) specifically addressed birth registration of adopted child. According to her, every birth, including for adopted child, also needs to have written and authentic evidence as it can prove a person's definite identity and has an impeccable strength of evidentiary that can be seen on the birth certificate issued by a competent authority issuing the certificate, which is the Population and Civil Registration Agency.

Meanwhile, Udia (2012), who examined the birth registration of extramarital child, stated that in Jombang the level of knowledge on the importance

\footnotetext{
* Corresponding Author

Phone : +6283870997559

Email : prastyoharie@gmail.com
} 
of birth certificates is considered less thorough, and this is proven with many people in Jombang, through dispensation program of birth certificate registration service, who have not possessed birth certificate, both birth for certificate for legitimate child and extramarital child.

Meanwhile, related to death registration, results of previous study is really minimal. Some studies that could be mentioned here is a study from Rao, et. al (2010) about death in Central Java, which concluded that death registration with cause of death is feasible to be applied in Indonesia through collaboration between health sector and population administration service agency.

Slightly different with the study by Rao is a of study result from PUM Research and Development Center and Population of the Research and Development Agency of the Ministry of Home Affairs (2014) concerning the registration of birth and death certificates showed that public awareness to report the events of birth and death is still low, the implementation of registration by the implementing agency is also not yet conducted in a proper and smooth system.

The studies mentioned above prove that the registration of birth and death in Indonesia, despite its legal framework, turned out in its implementation is not too encouraging. The data collected by the Indonesian Child Protection Commission (KPAI), the Ministry of Social Affairs, and UNICEF show that there are still many Indonesian children who do not have birth certificates.

The data from the Ministry of Social Affairs, for instance, recorded that there are 40 percent of Indonesian children or 84 million of Indonesian children who do not have birth certificates (Sindonews, May 22, 2015). Meanwhile, according to UNICEF (2015), as many as 60 percent of toddlers (under five years old) in Indonesia do not have birth certificates or 6 out of 10 children in Indonesia do not have valid birth identity. In fact, the commissioner of KPAI Susanto (in Tempo, May 1, 2015) stated that there are 83 million children in Indonesia who do not have birth certificates.

Meanwhile, related to death registration, the initial information of this study shows concern. Quoting the statement of the Director General of Population and Civil Registration Zudan Fakrulloh Arif, so far there is still a gap between the issuance of birth certificate and death certificate (Indopos, 09.29.2015).

According to Zudan, in some regions apparently the death certificate registration is not recorded properly.

The Ministry of Home Affairs (MOHA) found in the data of population administration information system (SIAK) in several regions that there are still regions which death certificate of citizens is amounted to zero. "It means that there is no one died that the data is not recorded in SIAK of the Mininistry of Home Affairs. This felt not possible that in one year in a distruct there is only one person who died, "he said. Zudan then cited Balikpapan City, East Kalimantan. Of the total population of approximately 700 thousand inhabitants, in a month there are approximately 1,204 death certificates issued.

In addition, other data showed that in Boyolali, for example, during 2014 there was only 55 per cent of the total deaths reported and made into death certificate (Population and Civil Registration Agency of Boyolali District, in Sigit, 2014). Then again with Serang District. There, even though the government has provided funding claims of $\mathrm{Rp} 1$ million per reporting of death, but only 70 percent of people who take care of reporting the death certificate (Serangpost, 2015).

Then, how did that happen? Referring to reviews written by the World Bank and WHO (2014), WHO (2014), Harmadi (2015), Hasibuan (2015), Tinambunan (2105), United Nations (2014), Wahyudi WP (2015), Zahr, et.al (2015 ), Phonde (2014), Susanti (2014), Anggraeni (2014), Rahmawati (2014), the Ministry of Administrative and Bureaucratic Reforms (2014), and Wirjatmi (2006), apparently the implementation of the existing birth and death registration still has many obstacles.

Applicants on the internal side have their urge and obstacle to apply. The urge is to get status and legal protection, access to other services, and sanctions make the applicants feel driven to do the reporting. However, from the internal side, hampered by the conditions of culture, economy and education.

On the external side, the applicants are constrained by barrier to reach the implementing agencies, such as distance, cost, requirements, and reporting mechanism of birth and death registration. If viewed from the implementation registration abroad, commonly only involves the applicants and the service of health/death to take care of birth and death certificated. While in Indonesia, it still involves the applicants, health services, and public institutions like Neighborhood Organization (RT)/ Community organizations (RW) and Urban Village/ Village offices.

On the other side, the implementing agency itself in carrying out the registration of birth and death is still constrained by inhibiting factors of human resources, management and infrastructure. While driving factors such as technology, innovation and incentives in District/City are still different.

Summarizing the above review, this study makes mapping framework on the condition of the registration of birth and death in Indonesia as 


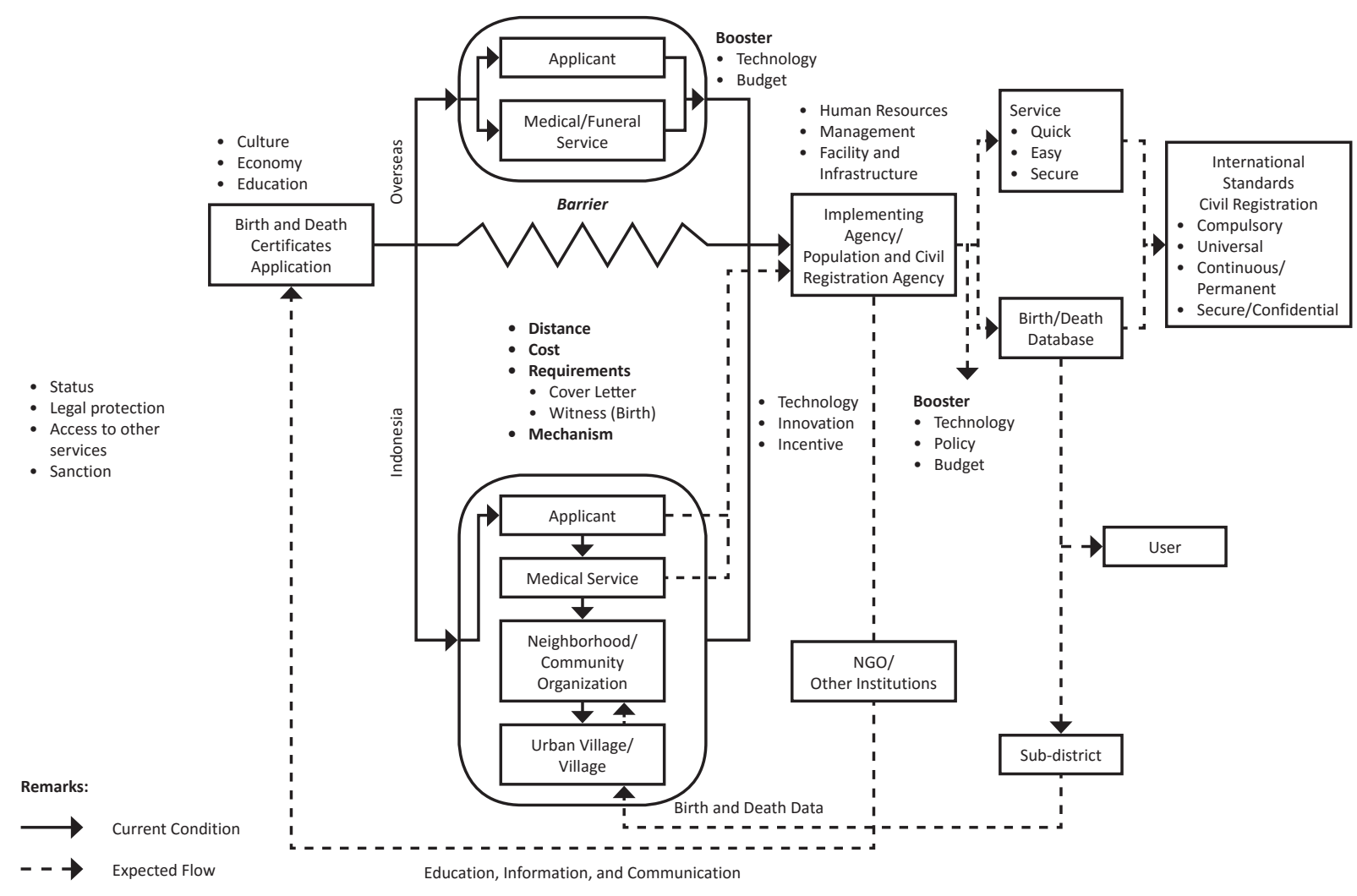

Figure 1. Mapping Framework on the Implementation

depicted in Figure 1.

The flow of image above was made in order to see the practice in the field regarding the registration of of birth and death, and the factual driving and inhibiting factors in the field for the applicants and the implementing institutions. Thus, the result of the registration process will produce a service that is fast, easy, safe and generates a database of birth and death in accordance with international standards. Through this research can be seen cooperation practices of the implementing intitutions with NGOs or other institutions to improve the scope of birth and death registration.

Based on the mapping framework, can be described the framework of the current study. Figure 2 depicts that this research aims to understand the practice of reporting and registration of birth and death at the level of the implementing institutions (the Population and Civil Registration Agency), District, Sub-District/Village and RT/RW.

With the above issue, it cannot be denied that the registration of birth and death clearly leave an issue. The issue that is often raised is in terms of requirements and bureaucratic registration mechanism, innovation/breakthrough that is not thorough in each district/city, and barriers at the level of the implementing institution. These conditions are participating in resulting the implementation of birth and death registration not to be as expected by the government.
Therefore, the study about the implementation of birth and death registration becomes important and relevant. To review it, this study is proposing two main questions. First, how is the real condition of the practice of birth and death registration in the regions viewed from requirements and mechanism aspects? Second, what are the issues, implications, and causative factors of the mechanism of birth and death registration in the region?

\section{MeThoD}

In order to resolve the various issues as described above and answer the following questions proposed, this study utilizes descriptive method, which is more to describe the studied object and analyze it based on the concept that has been put forward. Descriptive method is chosen because the researcher wants to obtain an illustration or a description of the phenomena that occurs in the field regarding the practice of birth and death registration in the District/City in terms of requirements and registration mechanism aspects.

By doing so, it is expected to be known and understood the comprehensive overview of the implementation of the registration. Based on the type, this study utilizes a qualitative approach and focuses on the results of field interview and the supporting secondary data. In addition, due to the limitation of time and cost, the study is conducted only on Indonesian citizens in two cities and two 


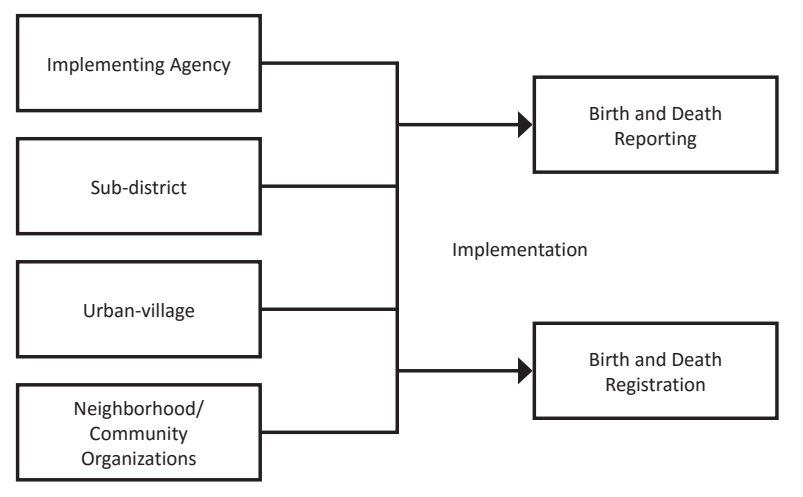

Figure 2. Practice of Reporting and Registration of Birth and Death

districts, namely Serang City and Cirebon City, as well as Lebak District and Cirebon District.

The data collection is conducted primarily and secondarily. Primary data collection is conducted by interviewing the officials who understand the policies in the field of civil registration, the laws, and the issues experienced by the community. Interview is also conducted with the community (applicants) who apply for birth and death certificates. Furthermore, observation/direct observation in the field is also conducted to support the result of field interviews.

Meanwhile, secondary data collection is conducted by gathering local regulations and common regulations related with civil registration, data on the number of birth and death of the last 3 (three) years, other secondary data, and other data such as journal writing, scientific magazines, and relevant research results.

Table 1.

Innovation on Birth and Death Certificates Service in Research Location

\section{RESULT AND DISCUSSION}

In the process of birth and death registration, it could be say that almost all of these research regions have had innovation. The said innovation is a proactive service that includes services of civil registration application for birth certificate and death certificate. However, the service is not all reaching down to the village level. Each region adjusts its own ability to perform the service, such as reaching out just up to the sub-district, reaching out to urban-village, or taking proactive service to schools, public centers, and simultaneously with other communal activities.

The proactive service is considered effective because other than reaching community that are hard to reach, it is also beneficial to concurrently conduct dissemination to the community. There is not much difference between the service of birth and death, because generally the proactive service includes all civil registration service. In Serang City, the service of death registration is directly by Echelon IV officials to ensure data verification. While in Cirebon City, death registration is handled together with the change of Family Card (KK).

The breakthrough of service conducted by each region has the same objective that is to help the community to get population service. But the breakthrough is mostly not yet regulated with the policy of institutions heads or local regulations so that each region put its maximum effort in providing easiness without definite regulations from the central government.

As a result, the comparison of the number of birth and birth certificate, the same with the

\begin{tabular}{|c|c|c|c|}
\hline \multicolumn{2}{|c|}{ Municipality } & \multicolumn{2}{|c|}{ District } \\
\hline Serang City & Cirebon City & Lebak District & Cirebon District \\
\hline
\end{tabular}

\begin{tabular}{|c|c|c|c|}
\hline \multicolumn{4}{|c|}{ Innovation on Birth Certificate Service } \\
\hline $\begin{array}{l}\text { - Proactive service in urban-vil- } \\
\text { lage level }\end{array}$ & $\begin{array}{l}\text { - Proactive service } \\
\text { - Online service }\end{array}$ & $\begin{array}{l}\text { - Proactive service to sub-dis- } \\
\text { tricts }\end{array}$ & $\begin{array}{l}\text { - Proactive service } \\
\text { - Service of Regional Technical } \\
\text { Implementation Unit (UPTD) } \\
\text { and the Capability Develop- } \\
\text { ment of Registry Officers in } \\
\text { Village (Plan of 2016) }\end{array}$ \\
\hline
\end{tabular}

\begin{tabular}{|c|c|c|c|}
\hline \multicolumn{4}{|c|}{ Innovation on Death Certificate Service } \\
\hline $\begin{array}{l}\text { Because of the small number, } \\
\text { the service is directly handled } \\
\text { by echelon IV officials, so that } \\
\text { the data verification is more } \\
\text { definite, the application can } \\
\text { be applied during the proac- } \\
\text { tive service of birth certificate }\end{array}$ & $\begin{array}{l}\text { - The service is at the same } \\
\text { time with the change of Fami- } \\
\text { ly Card (one package) }\end{array}$ & $\begin{array}{l}\text { - Proactive service to sub-dis- } \\
\text { tricts }\end{array}$ & $\begin{array}{l}\text { - Proactive service } \\
\text { - Service of Regional Technical } \\
\text { Implementation Unit (UPTD) } \\
\text { and the Capability Develop- } \\
\text { ment of Registry Officers in } \\
\text { Village (Plan) }\end{array}$ \\
\hline
\end{tabular}

Source: Field Data Processing, 2015 

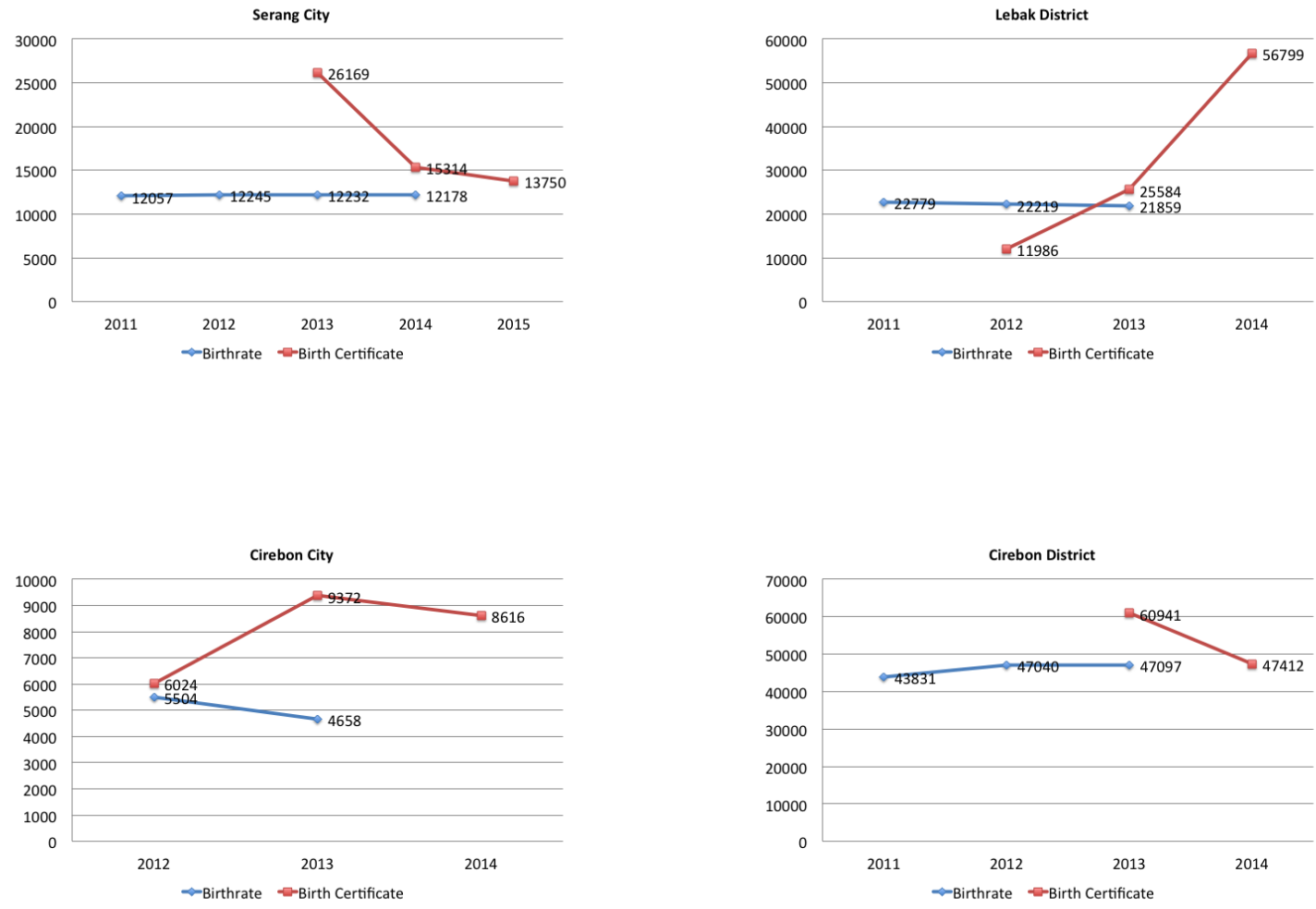

Source: Field Data Processing, 2015

Figure 3. The Comparison of Birth and Birth Certificate Numbers in Research Location

number of death and death certificate, is not always the same. Likewise, there is a discrepancy of data from Statistical Center Agency (BPS) and Population and Civil Registration Unit (Dukcapil).

\section{A. The Comparison of the Number of Birth and Death Certificates}

The data of birth issued by the Agency of Population and Civil Registration Unit (Dukcapil) is the total data of the birth certificates issued in one year. Meanwhile, the birth data issued by BPS is the total number of births that happened in one year. In general, the four research locations have higher birth certificate number than birth number. This is because on the year calculated, the number of birth certificate application is not only from the birth that year, but also from the previous years. From four research locations, only Lebak District that has the scope of birth certificates which then drastically increase on the following year.

The decrease in the scope of borth certificate occurs in the other three locations on the registration after 2013, namely Serang City, Cirebon City, and Cirebon District that tend to be stable on its service scope. But a quite significant increase occurs in Lebak District since 2012. The breakthrough of proactive service and the easiness of birth certificate procedure without using the cover letter from neighborhood/community organizations are considered to have contribution on the increase.

Meanwhile, related to death, this study formulated a definition that the data of death as released by Population and Civil Registration Agency is the data on the number of death certificates issued within one year. While the data of death from BPS is the total number of deaths that occur within one year. Despite the limitation on the data collected in this study, but it can be seen that the number of death certificates in all research locations is much lower than the number of deaths from BPS.

The location that experiences an increase on the scope of death certificate in this study is Cirebon City and Cirebon District. Cirebon City has a quite significant raise if compared to Cirebon District because of the innovation on death certificate service that is at the same time with the service of family card. To put it simply, below is illustrated a comparison graphic.

\section{B. The Implementation of Birth Certificate Registration}

The requirements and mechanisms conducted in four research locations (Serang City, Cirebon City, Lebak District, Cirebon District) in general are in 

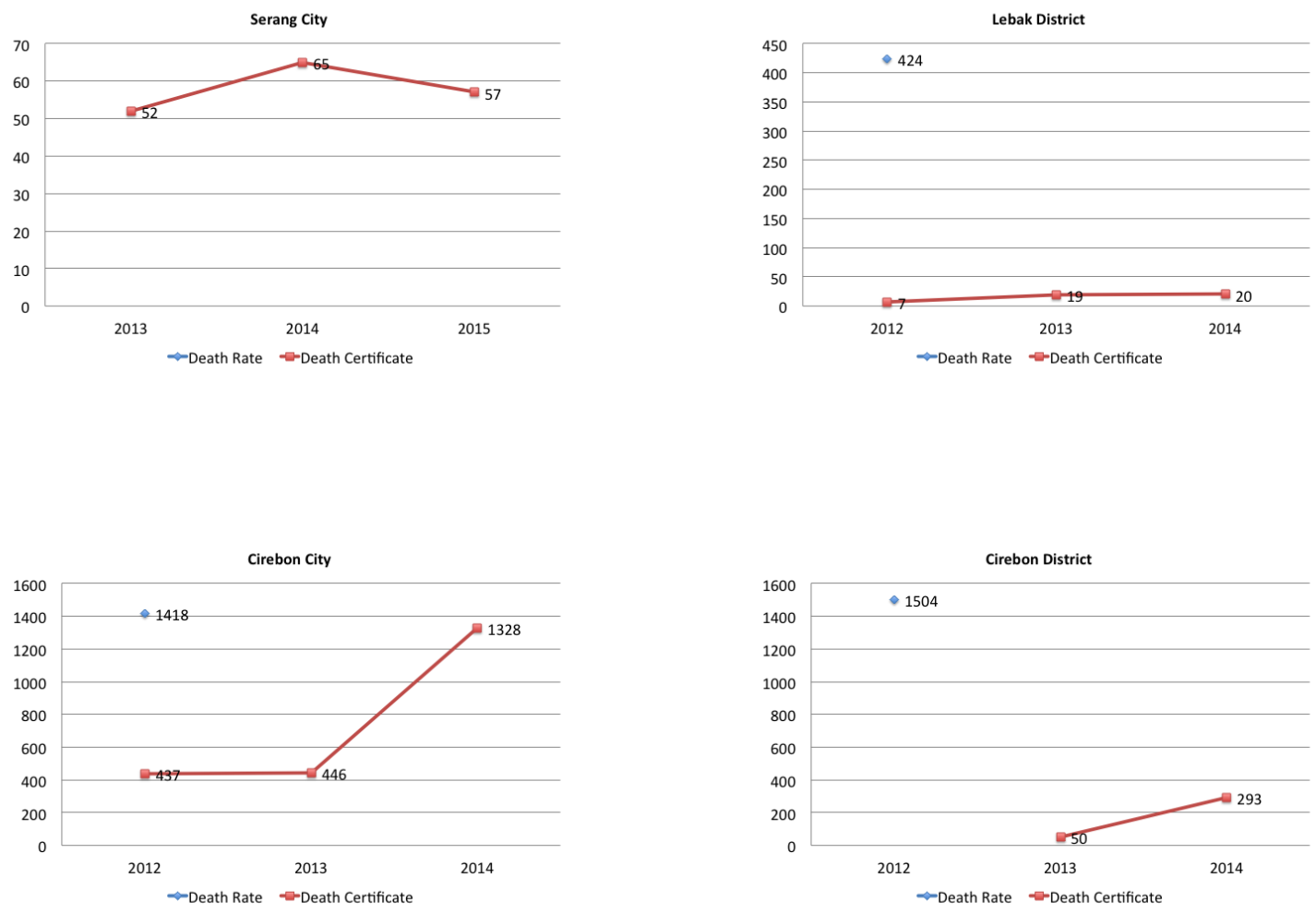

Source: Field Data Processing, 2015

Figure 4. The Comparison of Death Rates and Death Certificates in Research Location

accordance with the Presidential Decree No. 25 of 2008. Certainly the implementation still consider the "convenience" provided by Law No 24 of 2013, like the principle of domicile and the elimination of the state court ruling for the application procedure that exceeds one year. Specifically in Cirebon District, there is a local policy in the level of Population and Civil Registration Agency about the application of birth certificate, which is an additional requirement of the power of attorney and the statement of the parents. The power of Attorney is used on the application that is represented by another person or through a service.

Although on the regulation of the Presidential Decree No 25 of 2008 the registration of birth certificate is conducted without any cover letter from neighborhood/community organizations as the perquisite for birth certificate, but in practice 3 out of 4 locations still impose the Cover Letter from neighborhood/community organizations. The imposition of the Cover Letter from neighborhood/ community organizations is a product of local policy at district/city level that still regulate the need for permit/reference letter for population or governance administration affairs.

In research locations, only Lebak Districts that does not impose the cover letter from neighborhood/community organizations because it is indeed not required on the Presidential Decree No 25 of 2008. Beside to make it easy for the community, the capability of neighborhood/ community organizations human resources are still acknowledged to be lacking in conducting administration service properly.

Table 2.

Practices of Birth Reporting in the Level of Neighborhood/Community Organizations, Sub-village/Village

\begin{tabular}{llll}
\multicolumn{2}{c}{ Municipality } & \multicolumn{2}{c}{ District } \\
\multicolumn{1}{c}{ Serang City } & \multicolumn{1}{c}{ Cirebon City } & \multicolumn{1}{c}{ Lebak District } & \multicolumn{1}{c}{ Cirebon District } \\
\hline $\begin{array}{l}\text { With cover letter of Neighbor- } \\
\text { hood/Community Organizations }\end{array}$ & $\begin{array}{l}\text { With cover letter of Neighbor- } \\
\text { hood/Community Organizations }\end{array}$ & $\begin{array}{l}\text { Without cover letter of Neigh- } \\
\text { borhood/Community Organi- } \\
\text { zations }\end{array}$ & $\begin{array}{l}\text { With cover letter of Neighbor- } \\
\text { hood/Community Organizations }\end{array}$ \\
\hline
\end{tabular}

Source: Field Data Processing, 2015 
Table 3.

The Practices of Death Report in the Level of Neighborhood/Community Organizations, Urban-village/Village

\begin{tabular}{|c|c|c|c|}
\hline \multicolumn{2}{|c|}{ Municipality } & \multicolumn{2}{|c|}{ District } \\
\hline Serang City & Cirebon City & Lebak District & Cirebon District \\
\hline $\begin{array}{l}\text { There are only some neighbor- } \\
\text { hood heads who handle death } \\
\text { certificate } \\
\text { *the processing is dominated by } \\
\text { Chinese and non-Muslim }\end{array}$ & $\begin{array}{l}\text { There are only some neighbor- } \\
\text { hood heads who handle death } \\
\text { certificate } \\
\text { *the processing is dominated by } \\
\text { Chinese and non-Muslim }\end{array}$ & $\begin{array}{l}\text { There is no neighborhood head } \\
\text { handling death certificate } \\
\text { *the processing is dominated by } \\
\text { Chinese and non-Muslim }\end{array}$ & $\begin{array}{l}\text { There are only some neighbor- } \\
\text { hood heads who handle death } \\
\text { certificate } \\
\text { *the processing is dominated by } \\
\text { Chinese and non-Muslim }\end{array}$ \\
\hline
\end{tabular}

Source: Field Data Processing, 2015

The understanding of the community or local governments still refers to the notion that all administrative regulations, both population and other related to urban-village or above must be with the permit/known by neighborhood/ community organizations. For the application of birth certificate which is the product of state, in reality does not require the permit/reference from neighborhood/community organizationss that leaves the impression that the cover letter from neighborhood/community organizationss is more "powerful" than other population documents like ID card (KTP) or Family Card (KK) So, KTP and KK are clearly the proof of domicile or existence of a citizen in the neighborhood area. The notification of new member because of birth in neighborhood area is actually can be done after the process of birth certificate is completed and issued, which later can be used to renew family card and not the other way around.

\section{The Implementation of Death Certificate Registration}

The requirements and mechanisms conducted in four research locations are also in accordance with the Presidential Decree No 25 of 2008. But in the implementation of death certificate registration, which referred to Law No 24 of 2013, not all death registration is conducted by neighborhood Head.

So that in practice, there is only a small number of neighborhood head that conduct the process of death certificate of its citizen in accordance with the notion of Law No 24 of 2013. For the Government of Serang City, it has additional policy about the requirements imposed, that is the addition of the attachment of birth certificate and ID card of the person who died. This head's policy is conducted to avoid the misuse of population data and documents.

The processing of death certificate in all research locations is still dominated by non-Muslim and Chinese citizens. The community, especially the majority of Muslims, have not feel motivated to directly process death certificate immediately. The community just process the death certificate if it is required for other arrangement needs, for example to process Pension Saving and Insurance
(TASPEN) of the family, to take care of inheritance, insurance claims, etc. The death certificate is yet to be understood as an important document and has benefits for the family of the dead. In addition to other arrangements, there are still many government agencies/institutions, insurance companies, and banks that facilitate the requirements by allowing birth certificate in lieu of death certificate.

The request of death certificate is much less than the request for birth certificate, so that innovation related to death certificate is not yet a priority. However, the proactive service that aims more on birth certificate may also include a request for death certificate. Request of death certificate is generally directly handled by officials of echelon IV because the number is very small. Since it is handled directly by the said authorities, the verification of data is more secure and the issuance process is faster. In Cirebon City, the processing of death certificate as one package whenever the Family Card because of the death of a family member. The death certificate is still issued remain although not requested by family members.

\section{Registration/Recording of Birth Data}

On technical implementation, like the filling of Form F-2.01 for Birth Declaration Letter issued by Village or Urban-Village, does not fully use the form in accordance with the Minister of Home Affairs Regulation No 19 of 2010 about Form and Book Used for Population and Civil Registration. This form is used only in Serang City and Cirebon District. Cirebon City chooses to use a form of the previous Minister of Home Affairs Regulation (Minister of Home Affairs Regulation No 28 of 2005) and Lebak District chooses to make its own format to ease the service.

The downside of Birth Declaration Letter Form issued by Urban-Village/Village is on the format which filling process is difficult because it is detailed, rigid, and too small to be manually written, leaving it vulnerable to error in writing or emptied data. Some regions that are supported by adequate facilities and infrastructure such as the competence and quality of human resources and the availability of computer device are capable to issue this form with computer 
printout. However, in the regions with still limited facilities and infrastructure will certainly complicate the service and result vulnerability of error data information for birth certificate service. The regions that are still forced to use Form of the Regulation No 19 of 2010 are facing many filling issues such as incomplete data and susceptible to errors in data due to small writing space.

Therefore, many regions start to use old form that is considered simpler and easier to be filled, or to make their own form to ease the service. District/ city that uses the form of birth declaration letter from the old regulation tends to be more complete although not as complete as the new form. The difference in the use of form can cause the database record to not be maximum because not all data are recorded.

\section{E. Registration/Recording of Death Data}

Similar to the implementation of birth certificate registration, the implementation of death certificate registration is also not yet maximum. The technical implementation like the filling of Form F-2.28/F-2.29 for Death Declaration Letter issued by Village or Urban-Village not yet fully uses the form of the Minister of Home Affairs Regulation No 19 of 2010 about the Form and Book Used for Population and Civil Registration. Form for the processing of Death Certificate is used in Serang City and Cirebon District, just like the implementation of birth certificate. Cirebon City chooses to use the format of the pervious regulation (Minister of Home Affairs Regulation No 28 of 2005) and Lebak District choose to make its own format to ease the service.

The form used for the issuance of Death Declaration Letter is similar to the form for birth certificate. This form still has the same drawbacks, namely a difficult format for filling process as it is detailed, rigid, and too small to be manually written, leaving it vulnerable to written error and emptied data. Some regions supported by adequate facilities and infrastructure such as the competence and quality of human resources and the availability of computers device are capable of issuing this form with computer printout. However, the regions with still limited facilities and infrastructure will certainly complicate the service and result vulnerability of error information/data for death certificate service. The regions that are still forced to use Form of the Regulation No 19 of 2010 are facing many filling issues such as incomplete data and susceptible to errors in data due to small writing space.

The implementation of death registration is similar with the implementation of birth registration. Some regions start to use the old form that is considered simpler and easier to be filled, or to make their own form to ease the service. District/ city that uses the form of birth declaration letter from the old regulation tends to be more complete although not as complete as the new form. The difference ij the use of form can cause the database record to not be maximum because not all data are recorded.

\section{F. Issues, Influencing Factors, and Its Implications}

In this section, will be presented various issues, influencing factors, and also the following implications. This study found several issues related to registration of birth and death. Among the issues is first, the issue at the level Population and Civil registration Agency is the request of birth and death certificate with incomplete requirements, the Form of Birth and Death Declaration Letters that are not filled completely, and frequently encountered differences of child's name or the name of the parents in the required documents. The implications of such issus is the process of issuance becomes prolonged or obstructed, the database input in the system is incomplete, vulnerable to data writing error, and susceptible to the misuse of data because the form is not filled out completely.

The causative factors are the low awareness/ concern on the procedure and requirements for the application of birth and death certificated in applicant level, the lack of verification in village/ urban-village level, the lack of awareness of the officers and the applicants on the birth and death

Table 4.

The Conformity of the Form of the Minister of Home Affairs Regulation No. 19/2010 and the Data Elements Rrecorded in the Urban-Village/ Village

\begin{tabular}{|c|c|c|c|}
\hline \multicolumn{2}{|c|}{ City } & \multicolumn{2}{|c|}{ District } \\
\hline Serang City & Cirebon City & Lebak District & Cirebon District \\
\hline $\begin{array}{l}\text { In accordance with the Minister } \\
\text { of Home Affairs Regulation } \\
\text { No. } 19 / 2010\end{array}$ & $\begin{array}{l}\text { Use the old format (the previous } \\
\text { regulation of the Minister of } \\
\text { Home Affairs) }\end{array}$ & Use its own form & $\begin{array}{l}\text { In accordance with the Minister } \\
\text { of Home Affairs Regulation } \\
\text { No. } 19 / 2010\end{array}$ \\
\hline $\begin{array}{l}\text { Still found empty/passed } \\
\text { column }\end{array}$ & $\begin{array}{l}\text { The filling is complete of } \\
\text { compare with the use of new } \\
\text { form }\end{array}$ & $\begin{array}{l}\text { The form is filled completely, } \\
\text { but only basic data for registry } \\
\text { book }\end{array}$ & $\begin{array}{l}\text { Still found empty/passed } \\
\text { column }\end{array}$ \\
\hline
\end{tabular}

Source: Field Data Processing, 2015 
certificated data filling on the said form.

Second, the issues that often occurred at the level of the applicant, among others: The lengthy duration to process the completion of the required documents, especially birth/death declaration letters; the people are deliberately delaying the making of birth certificate; and the request of birth certificate for adults is minimal on the requirements. The implications of such issues are the process of issuing a birth certificate/death certificate will take some time (long), birth certificate scope is not optimal, and the application is obviously difficult to approve without clear requirements so it causes the Population and Civil Registration Agency to be in doubt in issuing birth certificate. The factors that cause it is the difficulty to gain access to services at the level of neighborhood/ community organizations, Urban-Village/Village, and even to the Population and Civil Registration Agencies, especially in districts or areas that have limited access, and time that collides with the work; children of unregistered marriage's birth certificate tend to be delayed or not created because it only listed the name of the mother.

In certain places, it is still a taboo in society. For the late or lengthy submission of birth certificate, it will make the applicants have difficulty in collecting the requirements such as witnesses and Birth Declaration Letter from midwife/doctor/ hospital.

Third, the issued experience on the level of urban-village/village is the difficulty to fill the form of Birth Declaration Letter F-2.01 and Form of Birth Declaration Letter F-2.28/F-2.29 in accordance with the Regulation of the Minister of Home Affairs No 19 of 2010 and the error cause by the writing will result in the incomplete form filling, hinder the process of application to be longer and vulnerable to error in the writing of data for the processing of birth certificate in the level of implementing institution.

The causing factors are the format of the Birth Declaration Letter that is too detailed, small and rigid making it difficult to fill, the human resources capacity in the urban-Village/Village varied, generally the ability to provide services is limited because of the number and age of the officers, and the lack of quality and knowledge of urban-villages / village officers in the population administration service.

Fourth, theissue experienced byneighborhood/ community organizations, among others, is issue related to mistakes in writing cover letters for requesting birth and death certificates that will impede the application process and susceptible to errors of writing data for the process of birth certificate. The causative factor is the lack of quality and knowledge of neighborhood/community organizations officers in the administration service of citizenship. Efforts that should be made to improve the performance of the neighborhood/ community organizations is through dissemination, training, and involvement as a team of citizenship administrative service to improve the service at the level of neighborhood/community organizations.

Fifth, the regulation made by the government to simplify and facilitate turned out to cause other issues. In this case, the principle of domicile impede the handling of patients who live outside the service area of the local Population and Civil Registration. As a result of the principle of domicile being used, the making of birth certificate directly at the hospital is not always smooth, as many residents patients who live outside the coverage area of the Population and Civil Registration service. As a result, birth certificate service cannot be conducted for the residents who live outside the coverage area of the related Population and Civil Registration. In addition, the process to obtain the National Identity Number (NIK) must go through urban-village because the family card must be updated. So that the service is not directly obtained, as there is still some procedures that must be handled on urban-village level.

The late processing of certificate based in domicile principle is vulnerable to wrongdoing, because the applicant can use various reasons to make another birth certificate. Besides, there is still found a difference of name in family card and name in marriage certificate to take care of birth certificate, and there is still a lot of fake marriage certificate. On immigration side, the requirement for marriage certificate must be legalized by Office of Religious Affairs (KUA). Too bad, the Population and Civil Registration Agency only has the authority for formal verification. When something happens, the Population and Civil Registration Agency is also requested to be a witness, if anything happened Population and Civil Registration Agency is always involved in court that it is time and money consuming.

From the side of time, the processing of death certificate in all locations is classified as moderate to fast after processed in the level of Population and Civil Registration Agency. In urban areas, the collection of requirements tends to be faster than district areas, because the factor of access to the level of neighborhood/community organizations and urban-village/village. Because the proposal for death certificate is generally lacking in all research locations, then the application process is quick and directly handled by echelon IV officials.

From the side of money, the processing of death certificate is categorized as moderate to expensive. Similar to birth certificate, the factors of distance, service access to neighborhood/ community organizations and urban-village/ village as well as access to the service of Population 
and Civil Registration Agency are influencing the transportation cost on the processing of death certificate. The processing cost in urban areas is cheaper than district areas because the influence of transportation distance and cost. The processing cost becomes expensive when choosing to use the service because of the occupancy/the lacking of time to do the application alone.

\section{G. Solution Alternatives Offered}

From various issues described above, in reality there are some solutions that need to be offered to solve the issues. In this section will be described two possible solutions, namely simple short-term solution and comprehensive long-term solution.

As a short-term solution, the first thing that can be done is Population and Civil Registration Agency conduct dissemination and training for urban-village/village officers. It is expected that citizenship administration service and tasks can be running well. The development of the role of urban-village officers to be registry officers is also an alternative to improve the quality of data and service in the level of urban-village/village.

Second, the applicants expect a shortcut to the bureaucracy lane for the processing of birth certificate and the issuance of death declaration certificate better not to be conducted manually, but with integrated system to the Population and Civil Registration Agency so that it will save time and money; dissemination with people of unregistered marriage to take confirmation hearing for those who have done it and suggesting registered marriage to those who have not; The imposition of sanction for those who are late in processing is also an alternative so that there will be a community drive to take care of their children's birth certificates.

Third, the government of urban-village/ village must develop it officers' capability with dissemination, training, and involvement as a team of citizenship administration service for the development of service at the level of urbanvillage/village and also the level below, which is neighborhood/community organizations, as well as preparing the supporting facility to ease their service in addition to making simpler for without overlooking the level of security, and data quality that want to be recorded.

Meanwhile, for long-term solution, this study makes several categories as a form of solution. First, fixing the database. Birth and death certificates must be input as database, because they will be beneficial for many things, such as the evidence when there is a case of misuse document and data for other institutions. The database collected by each implementing institution must be linked to national database, so that the benefit can be wider, not only for development planning on local scale, but also national scale.

Although the database for birth and death is not yet hugely collected by the implementing agency, but in the future, the utilization of the data must be regulated more clearly. The database needs to be regulated by sides who are granted permission to view, acquire, or manage the database.

Second, enhancing the benefits of citizenship documents. To increase the scope of birth and death certificated, not only conducted through dissemination, imposition of sanctions, and proactive service. There needs to be an increase in benefits of the document itself. As long as people do not understand the benefits of birth certificate or death certificate, it will be difficult to alert the public to report birth or death event. Today among many citizenship documents, only ID card that has the highest value because it is used for a variety of matters.

A birth certificate is also beginning to be understood by the community as the official identity of a child, as well as the requirement for school entry, ID Card application, family card, marriage registration, passport making, job application, taking care of insurance, family allowances, pension funds, and to perform the pilgrimage. But a death certificate is not yet understood to have beneficial value by the community. The death certificate's benefit is not yet understood by the whole community in Indonesia.

The benefit of death certificate is understood only by people who are generally well educated, recognize the law, and live in urban areas. The death certificate is useful for remarry requirements (for widows/ widowers), to manage the split of inheritance, to take care of retirement fund, mourning fund, accident benefits, and insurance. However, not all communities in remote and isolated areas understand it. Even the people who live in urban areas whose knowledge of population administration is lacking.

From the finding result in the field, people who tend to not process their family's death certificates will burden the family left behind. With the making of a death certificate, it will automatically remove all demographic identity such as ID card and the name in the family card, which will be difficult for the family to take care of property taxes on inheritance and abandoned objects. While the cost to title transfer, so that the tax administration is easy, requires considerable expense.

While TASPEN itself still requires Death Declaration Letter from urban-village/village as a prerequisite for taking care of the pension fund and do not require death certificate. This shows that death certificate document that is legally valid from the state is lower than the Death Declaration Letter from Urban-Village/Village. For this reason, 
it is necessary to increase the incentives or benefits of Death certificate from the government. There should be a rule that requires the existence of death certificate for the administration procession in the sectors of banking, insurance, TASPEN, etc.

Third, use universal principles and international standards. The government's policy towards the convenience of birth and death certificate services must adhere to the international standards. Universally, anywhere the civil registration is revering to eventual principle. For now, the eventual principal is only listed on birth certificate, but the reporting uses the principle of domicile. In principle, the United Nations (2014) also has provided a reference of vital statistics system or civil registration must meet mandatory principles, generally accepted, continuous/permanent, and confidential. The principle of this obligation must be accompanied by the element of the imposition of delay sanctions as the control over society.

The local government has its own policy on the sanction or penalty for delay, so that there is no similarity between one region and other regions. Although in Law No 24 of 2013 there was no imposition of sanctions on the reporting of birth exceeding 60 days, and the reporting of death exceeding 30 days, the Governments needs to clearly regulate the late penalty so that it can be nationally similar.

Although Indonesia has many problems such as the population of the 4th largest in the world, a country with thousands of islands, high mobility and high birth, but a universal principle must still be held, so that in the future it is able to reduce the problem of civil registration that is even more complicated.

Fourth, fix the regulation. In terms of making regulations, the Ministry of Home Affairs is faced with the challenge to put forward the right basic principle at the beginning of the construction of population administration, so that what is being made is acceptable in all institutions. The current regulation is considered not to be ignorant with the emerging impact, so that occured innovation issues created by local governments.

The civil registration policy still considered to have weaknesses, because many people without authorization are still forced to be part of the system or procedure for birth and death certificate service. For example the cover letter from neighborhood/ community organizations as a prerequisite for Birth and Death Cover Letter. The result of the seminar of this study found that some regions no longer use cover letter from neighborhood and community organizations, such as Medan City, Sukabumi District, and Lebak District.

The official declaration of birth or death should be provided with a letter from an authorized party.
Birth and death can occur with medical or nonmedical practitioners.

The birth with medical assistance, like doctor/ medical officer can provide birth declaration letter. Likewise is with the death that occurred with medical knowledge. While the events of birth and death that occur outside the assistance of medical personnel (non-medical) require cover letter or statement of neighborhood/community organizations and local villages.

The new policy of civil registration should also consider in more detail about the processing of birth and death certificates that is late or happened long time ago, since many of the requirements are difficult to fulfil due to the loss of population data. With the enactment of Law No 24 of 2013, which adopts the principle of domicile for the birth and death, it is prone to wrongdoings.

For example, there are many people who make birth certificate again by admitting that the certificate owned is gone. The problem arises when the lost certificate is made in a place of birth that is different from the domicile. As a result, the bureaucracy becomes more difficult if requiring verification process of the implementing institutions in the place of origin to issue a birth certificate in the place of domicile.

The policy of civil registration needs to be more specific on the planning, so that it can be seen which group or region that needs to get attention priority from other regions. For example, the supply of blanks for population documents that does not comply with what the region needs. In some regions with Muslim majority, the supply of birth, death, and marriage certificate blanks is more plentiful. If the database is provided comprehensively, then the need for those blanks will be known for regions so that it will increase the fulfilment of need of the right regions.

The policy also needs to look and consider the culture of the community in a region, even to culture than has national impact. As an example, a birth certificate of a complete parents if compared to a birth certificate of just a mother before the law are the same, but that is not the case in society.

In Lebak District and the other areas in Banten, a child who was born to a mother is considered inferior in the eyes of the public, so people tend to avoid/postpone making a birth certificate. While at the national level, there is still a rejection of the prospective cadet in Academy of the Armed Forces or Police Academy if the cadet was born just to a mother.

\section{Conclusion}

Some locations have made breakthroughs, but are not much regulated by official policy. The breakthroughs are among other things: proactive 
service to the urban-village/ village, cooperation with the hospital for birth certificate service, the use of communication technologies (SMS, Internet) as a medium of service, and a plan to make One-Stop Service Unit (UPTD) or plan to assign urban-village/ village officers to become registry officers.

Therefore, the detailed arrangement in the form of formal policy becomes a necessity. One of the ways is to hold on to international principles and standards. In the principle the obligation, must be accompanied by the imposition of sanctions for the delay. The government needs to clearly regulate the late penalties that there will be national similarity. Besides, civil registration policy is still considered to have weaknesses, because there are many sides who are not authorized but are forced to be part of the system or procedure of birth and death certificates service. For example, cover letter from neighborhood/community organizations as a prerequisite for Birth and Death Cover Letter.

The declaration of birth or death should be provided a letter from authorized party. Birth and death can occur in medical or non-medical condition. In the medical birth and death, for instance, the doctor/ medical officer can use birth or death declaration letter. Meanwhile, the events of birth and death that occurred outside of the handling of medical personnel (non-medical) require a reference letter or a statement of local neighborhood/community organizations and urban-village. Government policy must be more specific in terms of planning so that there is a priority to the areas that really need assistance for documents/blanks.

Moreover, what also important is the revision of the Presidential Decree No. 25 of 2008. The requirement of name and identity of the witness that burdens the applicants and causes multiple interpretation at the level of implementing institutions should be deleted. Parental Statement and Birth declaration from Medical Officers), or Birth declaration from Urban-village/Village already have its own power instead of name and identity of birth witness. Additionally, neighborhood/community organizations is not part of the Population and Civil Registration Agency and has no relevance to authorize the service of birth and death certificates. More relevant requirements are given by authorized professionals/institutions in terms of birth and death.

In supporting the scope of birth and death certificate, and ease of access for applicants, as well as ease of work for the implementing institutions, the service better be delegated (authorization) at the level of urban-village/village or sub-district to be One-Stop Service (UPT) to reduce the long range of process to improve the quality of the officers as the registry officers to make them capable of conducting service and verification. Further study is necessary on the feasibility of this service along with the readiness of infrastructure, budget planning, and the supporting human resources. In addition, the service inurban-village needs to be supported by the Population Administration Information System (SIAK) integrated to Population and Civil Registration Agency (Dukcapil) to shorten the processing time of birth and death certificates.

\section{REFERENCES}

AbouZahr, C., de Savigny, D., Mikkelsen, L., Setel, P., Lozano, R., \& Nichols, E. et al. (2015). Civil registration and vital statistics: progress in the data revolution for counting and accountability. The Lancet, 386(10001), 1373-1385. http:// dx.doi.org/10.1016/s0140-6736(15)60173-8

Ambiyah, F. (2011). Analisis Akta Kelahiran Anak Adopsi Ditinjau dari Peraturan Perundang-undangan di Indonesia (Studi di Dinas Kependudukan dan Catatan Sipil Kota Semarang) (Undergraduate Thesis). Universitas Negeri Semarang.

Anggraeni, T. (2014). Menciptakan Sistem Pelayanan Publik yang Baik: Strategi Reformasi Birokrasi dalam Pemberantasan Korupsi. Jurnal Rechtsvinding, 3(3), 417-433.

Civil registration: why counting births and deaths is important. (2014). World Health Organization. Retrieved 6 September 2015, from http:// www.who.int/mediacentre/factsheets/fs324/ en

Dammar, S. (2015). 40 Juta Anak Tidak Punya Akta Lahir. SINDOnews.com. Retrieved 22 August 2015, from http://nasional.sindonews.com/ read/1004159/15/40-juta-anak-tidak-punyaakta-lahir-1432279757

Global Civil Registration and Vital Statistics: Scaling up Investment Plan 2015-2024. (2014) (1st ed.). Retrieved from http://www.who.int/ healthinfo/civil_registration/WB-WHO_ ScalingUp_InvestmentPlan_2015_2024. pdf?ua=1

The Government of the Republic of Indonesia., (2006). Law No 23 of 2006 about Citizenship Administration. Jakarta: Ministry of Law and Human Rights.

The Government of the Republic of Indonesia., (2008). The Presidential Decree No 25 of 2008 about the Procedures of Population and Civil Registration. Jakarta: State Secretariat.

The Government of the Republic of Indonesia., (2013). Law No 24 of 2013 about the Revision of Law No 23 of 2006 about Citizenship Administration. Jakarta: Ministry of Law and Human Rights.

Harmadi, S. (2015). Pencatatan Kelahiran dan Kematian: Hak Legal bagi Penduduk Indonesia. 
Presentation, Focus Group Discussion (FGD) at BPP Kemendagri.

Hasibuan, K., Anidya, K., \& Erwinsyah, M. (2015). Catatan Sipil di Indonesia. prezi.com. Retrieved 2 September 2015, from https://prezi.com/ zzqncgxl6ci0/catatan-sipil-di-indonesia/

Hindari data ganda, masyarakat diwajibkan buatakta kematian. (2015). serangpost.com. Retrieved 23 August 2015, from http://serangpost.com/ hindari-data-ganda-masyarakat-diwajibkanbuat-akta-kematian

Improving Mortality Statistics through Civil Registration and Vital Statistics Systems Strategies for country and partner support. (2014) (1sted.). Geneva. Retrieved from http:// www.who.int/healthinfo/civil_registration/ CRVS_MortalityStats_Guidance_Nov2014.pdf

Jackson, M., Duff, P., Kusumanigrum, S., \& Stark, L. (2014). Thriving beyond survival: Understanding utilization of perinatal health services as predictors of birth registration: A cross-sectional study. BMC Int Health Hum Rights, 14(1). http://dx.doi.org/10.1186/ s12914-014-0038-3

Julikawati, P. (2015). Separuh Anak Indonesia Tidak memiliki Akte Kelahiran / Tempo Nasional. Tempo Nasional. Retrieved 22 August 2015, from http://nasional.tempo.co/read/ news /2015/05/01/063662608/separuhanak-indonesia-tidak-memiliki-akte-kelahiran

Kementerian Pendayagunaan Aparatur Negara dan Reformasi Birokrasi - Top 99 Inovasi Pelayanan Publik di Indonesia. (2014). Menpan.go.id. Retrieved 17 October 2015, from http://www. menpan.go.id/berita-terkini/2300-top-99inovasi-pelayanan-publik-di-indonesia

Kurniawan, A. (2015). Pencatatan Pendudukan Kurang Baik, Disetiap Daerah hanya Satu Warga yang Meninggal?. indopos.co.id. Retrieved 21 November 2015, from http://www.indopos. co.id/2015/09/pencatatan-pendudukankurang-baik-disetiap-daerah-hanya-satuwarga-yang-meninggal.html

Phonde, P. (2012). Registration of births \& deaths act ppt. Slideshare.net. Retrieved 2 September 2015, from http://www.slideshare.net/ priyankaphonde/registration-of-birthsdeaths-act-ppt

Prasetya, T. (2012). Indeks Kepuasan Masyarakat pada Pelayanan Akta Kelahiran di Dispendukcapil Surabaya (Undergraduate Thesis). Universitas Pembangunan Nasional (UPN) "Veteran".

Principles and Recommendations for a Vital Statistics System. (2014) (3rd ed.). New York. Retrieved from http://unstats.un.org/ unsd/demographic/standmeth/principles/ M19Rev3en.pdf
Rahmawati, T., Noor, I., \& Wanusmawatie, I. (2014). Sinergitas Stakeholders dalam Inovasi Daerah (Studi pada Program Seminggu di Kota Probolinggo (SEMIPRO)). Jurnal Administrasi Publik (JAP), 2(4), 641-647. Retrieved from http://administrasipublik.studentjournal. ub.ac.id/index.php/jap/article/view/435

Rao, C., Soemantri, S., Djaja, S., Suhardi, S., Adair, T., \& Wiryawan, Y. et al. (2010). Mortality in Central Java: Results from the Indonesian Mortality Registration System Strengthening Project. BMC Research Notes, 3(1), 325. http://dx.doi. org/10.1186/1756-0500-3-325

Research and Development Agency Ministry of Home Affairs (BPP Kemendagri),. (2014). Registrasi Kelahiran dan Kematian: Suatu Penelitian terhadap Implementasi Kebijakan Bidang Administrasi Kependudukan di Daerah Kabupaten Bandung dan Daerah Kota Bandung Provinsi Jawa Barat. Jakarta: General Government and Citizenship Research and Development Center (Puslitbang PUM \& Duk).

Sejuta Penduduk Sukabumi Tak Punya Akta Lahir. (2016). Jabar.metrotvnews.com. Retrieved 20 August 2015, from http://jabar.metrotvnews. $\mathrm{com} / \mathrm{read} / 2015 / 08 / 18 / 159422 / \mathrm{sejuta}$ penduduk-sukabumi-tak-punya-akta-lahir

Sigit, A. (2014). Pengurusan Akta Kematian Minim, Dispendukcapil Jemput Bola. krjogja.com. Retrieved 23 August 2015, from http:// krjogja.com/read/229254/pengurusan-aktakematian-minim-dispendukcapil-jemput-bola. $\mathrm{kr}$

Sulfiani, A. (2012). Kualitas Pelayanan Akta Kelahiran pada Dinas Kependudukan dan Pencatatan Sipil Kabupaten Wajo (Undergraduate Thesis). Universitas Hasanuddin.

Susanti, S. (2014). Kualitas Pelayanan Publik Bidang Administrasi Kependudukan di Kecamatan Gamping (Undergraduate Thesis). Universitas Negeri Yogyakarta.

Syaibani, R. (2012). Peranan Dinas Kependudukan dan Catatan Sipil dalam Pelayanan Administrasi Kependudukan (Studi tentang Pengurusan Akta Kelahiran dan Akta Kematian di Kota Medan) (Undergraduate Thesis). Universitas Sumatera Utara.

Tinambunan, I. (2015). Pencatatan Kelahiran di Kabupaten Dairi dalam Rangka Pelaksanaan Administrasi Kependudukan Menurut Undangundang Nomor 23 Tahun 2006 Ditinjau dari Hukum Administrasi Negara (Undergraduate Thesis). Universitas Sumatera Utara.

Trilestari, E. (2014). Konsep-konsep Dasar Kualitas Pelayanan Publik (1st ed.). Aceh: Universitas Almuslim. Retrieved from http://fisip. umuslim.ac.id/index.php?option=com_phoca download\&view=category \&download=2: bah 
an-ajar-pelayan-publik\&id=1:all\&Itemid=57

UNICEF Indonesia - Perlindungan Anak - Sekilas

- Pencatatan Kelahiran. (2015). Unicef.org.

Retrieved 24 August 2015, from http://www. unicef.org/indonesia/id/protection_3149. html

Wahyudi, W. (2015). Lembaran Pembahasan FGD Badan Litbang Kemendagri: Penelitian Strategis Implementasi Pencatatan Kelahiran dan Kematian TA 2015. Presentation, Research and Development Agency Ministry of Home Affairs (BPP Kemendagri).

Wati, U. (2012). Proses Penerbitan Akta Kelahiran Anak Luar Kawin di Dinas Kependudukan dan Pencatatan Sipil Kabupaten Jombang (Undergraduate Thesis). State University of Malang. 